\title{
INNOVATION PRACTICES THROUGH KNOWLEDGE NETWORKS: PARTICIPANT OBSERVATION IN THE BRAZILIAN NAVY MANAGEMENT SCHOOL
}

\author{
Érica Von Raschendorfer Bastos Maia ${ }^{1}$, Felipe Maia Braga ${ }^{2}$ \\ and Liliane Magalhães Girardin Pimentel Furtado ${ }^{1}$ \\ ${ }^{1}$ PPGAD - Universidade Federal Fluminense, Rua Mário Santos Braga, S/N, $4^{\circ}$ andar, Prédio 1, \\ Campus do Valonguinho - Centro- Niterói - RJ, Brazil \\ ${ }^{2}$ PPGDEI - Pontifícia Universidade Católica, Rio, Rua Marquês de São Vicente, 225 casa XV - Gávea - RJ, Brazil
}

\begin{abstract}
The New Public Governance paradigm, which arose as a response to the needs of a public management that is oriented towards the satisfaction of real demands from citizens, has at its core the defense of networks as an essential element to the creation of public value. Assuming that an enabling public management environment, typical of this new context, permeates the management of the social capital, it is the social relations in the public sector that comprise an invaluable source of value creation. Therefore, this paper aims at investigating how the elements of the intellectual dimension may be articulated by public organizations in the process of solving real management problems, by means of knowledge networks. To this end, there has been carried out a participant observation (PO), which entailed the structuring and monitoring of the discipline "Improvement of Navy Logistical Support Processes", conducted at the Brazilian Navy Management School and taught within the graduate certificate program for supply officers. The research results show positive impacts of knowledge networks as a source of public value creation, confirming previous studies on the development of practices of public governance, with a focus on the coordination of resources of human, social, and organizational capital.
\end{abstract}

KEYWORDS

New Public Governance, Innovation, Knowledge Networks, Participant Observation

\section{INTRODUCTION}

The complexity of the operating environment of current public organizations has demanded equally complex solutions. According to Lindsay, Osborne, and Bond (2014) and Osborne (2017), the operating context of public organizations in the 21st century translates into a multidimensional, dynamic environment in which the co-production becomes intrinsic to the processes and practices of public management, making the greatest (and longest-term) contribution through the sustainable public services which characterize the newest paradigm of Public Administration and Governance called New Public Governance (NPG) (Osborne, 2017).

This new conceptual view has been progressively discussed on the literature related to public management, which reveals wider concerns about governance of more complex service delivery systems to citizens, in line with a more transactional view, extrapolating the limits of economic performance, characteristic feature of the managerial view, and including social and environmental aspects imposed by the relation with the actors involved.

In the Brazilian context, this new reality points to an overhaul in the public management and governance practices, bringing to light the importance of innovation and knowledge as essential elements to public value creation and bringing up the discussion of the "creation of state processes that enable agreement generation between actors, in the face of contexts where there is not any possible technical solution" (Fontes Filho, 2014).

The Brazilian Navy (MB, by its acronym in Portuguese), placed in the context of public organizations in the 21st century, seeks innovation models and practices focusing on real problems solving as a means of creating public value, in a sustainable way, highlighting the strategic importance given to the linking of resources of intellectual capital, which are People, Organizational Aspects, Procedural Aspects, Knowledge and Relational Aspects (Raschendorfer, 2019). 
It is in this framework that emerges a research problem which intends to identify how elements of intellectual dimension may be linked in the process of real management problems solution and fostering of innovation processes in the public sector, with a view to creating value. For this purpose, it has been taken into consideration in this study the fundamental aspects of the New Public Governance, the analysis of relational networks from the point of view of centrality, with applicability to the Brazilian Navy, being as the topic for research the Instruction and Training Center Almirante Newton Braga (CIANB, by its acronym in Portuguese), military school that conducts qualification courses related to public management in such armed force.

As a technique for data collection, it was applied the participant observation (PO), involving structuring and monitoring of the discipline "Improvement of Navy Logistical Support Processes", conducted by CIANB and taught within the graduate certificate program for Brazilian Navy supply officers, for the purpose of analyzing the impact on the formation and maintenance of relationships among actors; identifying the asymmetry of information among actors and its transformation; monitoring the following events, contributing to the understanding the phenomenon studied, in accordance with Abib, Hoppen, and Hayashi Junior (2013).

\section{BODY OF PAPER}

The challenges of forwarding the link of resources of human and organizational capitals for the sake of effective development of organizational capacities, contributing to the modernization of public management (SANTOS, 2016), in a setting of public sector downsizing and high administrative workload, is the main challenge found by public organizations in Brazil.

In this respect, the author states that a new movement in public management called New Public Governance - NPG is consolidated as a concept which is more aligned with the characteristics of current environment, or as defined by Osborne (2006), a new setting characterized by more participative management models, based on network management, co-production, flexibility in the use of management instruments, guided by new administrative theories, stressing the importance of social capital.

According to Ahn and Park (2018), the fundamental aspect of this dimension expressed by the relationship between individuals, being the people the primary elements. Subramony et al (2018) advocates that social relations are represented by relationships between team members, the information sharing, the reciprocity, the collaboration, and other structuring and cognitive elements figuring in the networks emphasize the importance of the individual in social context, highlighting, this way, the relevance of an appropriate setting of networks, reinforcing the importance of procedural attributes, included in the formal establishment of rules of conduct for participants (AHN e PARK, 2018).

Therefore, the most expressive role of networks to the organizational performance is to facilitate the obtainment of resources needed within the organization. In this sense, it is highlighted the supporting elements, which belong to the organization, which thereby holds the decision-making power, including: the definition of the structure of direct contacts, the establishment of formal groups and relational communication networks.

\subsection{Research Method}

This research was structured in three phases, as is described in Tables 1, 2 and 3, as follows:

Table 1. Research phases

\begin{tabular}{|c|c|c|}
\hline Phase & & Description \\
\hline $\begin{array}{c}\text { Phase } \\
1\end{array}$ & $\begin{array}{l}\text { Definition of the elements of } \\
\text { Intellectual Capital }\end{array}$ & $\begin{array}{l}\text { Identification of essential elements of Intellectual Capital (IC) and their characteristics. } \\
\text { (RASCHENDORFER, 2019). }\end{array}$ \\
\hline $\begin{array}{l}\text { Phase } \\
2\end{array}$ & $\begin{array}{l}\text { Structuring of Participant } \\
\text { Observation based on the } \\
\text { elements from Phase } 1 \text {; }\end{array}$ & Goal: comprehend the relationships between actors in knowledge networks \\
\hline $\begin{array}{l}\text { Phase } \\
3\end{array}$ & $\begin{array}{l}\text { Participant Observation in } \\
\text { the CIANB - }\end{array}$ & $\begin{array}{l}\text { Identify the relationship between actors when solving real management problems; } \\
\text {-It has been conducted a complete PO, divided into two categories: opportunity and } \\
\text { conversion. In four stages: (i) research preparation, (ii) entering the field, } \\
\text { (iii) observation (and analysis), and (iv) conclusion (and analysis). (Abib, Hoppen and } \\
\text { Hayashi Junior, 2013). }\end{array}$ \\
\hline
\end{tabular}

Source: own construction. 
Table 2. Structuring of research work

\begin{tabular}{|c|c|}
\hline Elements of Intellectual Capital & PO action planning \\
\hline People & Mapping of the networks elements; \\
\hline Organizational Aspects & Definition of formal rules to participants; \\
\hline Procedural Aspects & $\begin{array}{l}\text { Planning of themes and deadlines along with Technical Guidance Military Organizations } \\
\text { (OMOT, by its acronym in Portuguese); Activities foreseen in internal standards; }\end{array}$ \\
\hline Knowledge & $\begin{array}{l}\text { Connection of student officers with proposed themes for the discipline MPI, advisors } \\
\text { and the corresponding element in the primary network (OMOT) }\end{array}$ \\
\hline Relational Aspects & Definition of assignments to participants and assessment rules. \\
\hline \multicolumn{2}{|l|}{ Source: own construction. } \\
\hline \multicolumn{2}{|r|}{ Table 3. Stages of PO } \\
\hline Period/Stage & Supporting documents \\
\hline \multirow[t]{2}{*}{$\begin{array}{l}\text { August } 2018 \text { - December } 2018 \\
\text { Stage } 1 \text { - Natural intervention }\end{array}$} & Work observation by the researcher; initial assessments. \\
\hline & $\begin{array}{l}\text { Analysis of administrative documents; } \\
\text { Meeting with the OMOT so as to identify relevant research themes/problems; }\end{array}$ \\
\hline $\begin{array}{l}\text { March } 2019 \text { - August } 2019 \\
\text { Stage } 2 \text { - Artificial } \\
\text { participation }\end{array}$ & $\begin{array}{l}\text { Script for analysis of results - added to the script a guide to assess student performance } \\
\text { from the standpoint of utility, novelty, and applicability regarding the solutions } \\
\text { presented; }\end{array}$ \\
\hline
\end{tabular}

Source: Own construction.

\subsection{Results and Discussion}

The results of the PO are presented in Figures 1 and 2, as follows:

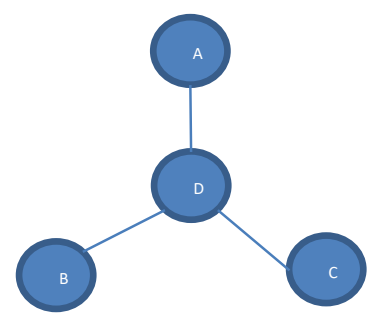

Source: own construction.

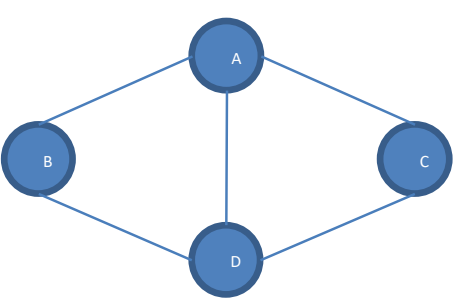

Source: own construction.

Figure 1. Contacts of the primary network

Figure 2. Contacts of primary network with the discipline MPI

It can be observed that the inclusion of the discipline "Improvement of Navy Logistical Support Processes" (MPI, by its acronym in Portuguese) in the syllabus of the graduate certificate program for supply officers has modified both the position and the number of contacts, as well as the information flow within the primary network. This self-same network is composed by: A - CIANB; B - Military organizations (OM) within the area of responsibility of the General Secretariat of the Navy; C - General OM; e D - OMOT. The substitution of the network center enhanced the information flow between network elements, and, as a result, leveraged the innovation and knowledge generation processes in the network (FREITAS, 2010).

\section{CONCLUSION}

In the analysis of the collected data during the PO, it was revealed the increase of contacts within the network, in addition to the distribution of centrality as far as the availability of information is concerned. This resulted in indirect costs reduction in audits and technical visits held by OMOT, thus also reducing the administrative 
workload and allowing for technological progress, reinforce the strategic importance of network configuration and appropriate organization, as advocated by Ahn e Park (2018).

The situation analyzed in this research stresses the importance of transformation of tacit knowledge into some explicit through sharing, as mentioned by Wang, Sharma, and Cao (2016), by means of which it is possible to improve productivity, absorption and capacity of innovating and supporting value creation, either through explicit (documents and reports, procedures and policies, or manuals) or tacit (experiences, insights, among others) knowledge sharing.

With regard to social capital, a facilitator of innovation processes, the approach of student officers to other network actors, as a way to seek understanding of the research theme and problem was beneficial. Besides, this placed a lot of emphasis on the even more expressive role of networks in organization performance, enabling the obtainment of the necessary resources, being in alignment with previous studies (e.g.: Cao, Ding, and Zhang (2016)).

To conclude, the most expressive result of this study highlights the importance of supporting elements in the networks. These elements belong to the organization, which thereby holds the decision-making power, which involves the control of the structure of direct contacts, the establishment of formal groups, methods, and routines, and relational communication networks. In this respect, it remains demonstrated that the articulation of social, human, and organizational capital may contribute to organizational outputs, as was pinpointed by Cao, Ding, and Zhang (2016), and Wang, Sharma, and Cao (2016).

\section{REFERENCES}

Abib, Gustavo; Hoppen, Norberto; Hayashi Junior, Paulo. (2013). Observação participante em estudos de administração da informação no Brasil. Revista de Administração de Empresas. São Paulo. 53 (6): 604-616. nov-dez.

Ahn, Se-Yeon; Park, Dong-Jun. (2018). Corporate social responsibility and corporate longevity the mediating role of social capital and moral legitimacy in korea. Journal of Business Ethics. v 8(1). p 137-152

Fontes Filho, Joaquim Rubens \& Picolim, Lidice Meireles. (2008). Governança corporativa em empresas estatais: avanços, propostas e limitações. Revista de Administração Pública. 42(6):1163-1188, nov/dez.

FretaS, Leandro Quintanilha (2010). Medidas de Centralidade em Grafos. Dissertação (Mestrado em Engenharia de Produção) - Universidade Federal do Rio de Janeiro - Programa de Engenharia de Produção - UFRJ/COPPE. Rio de Janeiro.

García-Villaverde, Pedro M.; Parra-Requena, Gloria; Molina-Morales, F. Xavier. (2018). Structural social capital and knowledge acquisition implication of cluster membership. Entrepreneurship \& Regional Development. 47(1): 143-146, maio.

Lindsay, Colin, Osborne, Stephen P., Bond, Sue. (2014). The New Public Governance and employability services in na era of crisis: challenges for third sector organizations in Scotland. Public Administration: 92(1), 192-207.

Osborne, Stephen P., (2006). The New Public Governance. Public Management Review (3):377-387.

Osborne, Stephen P., (2017). Public management research over the decades: what are we writing about? Public Management Review 19(2):109-113.

Radnor, Zoe, Osborne, Stephen P, Kinder, Tony, Mutton, Jean. (2014). Operationalizing co-production-in public services delivery. Public Management Review: 16(3): 402-423.

Raschendorfer, Érica von. (2019). A New Public Governance brasileira: uma proposta de modernização das práticas de gestão pública da Marinha do Brasil a partir das dimensões do Relato Integrado. Dissertação (Mestrado em Administração) - Universidade Federal Fluminense - Programa de pós-graduação em Administração - Niterói, Rio de Janeiro.

Santos, Priscila Ribeiro dos. (2016). Inovações participativas, diálogo social e construção de consensos. Revista de Administração Pública: 50(3): 501-511. maio-junho.

Subramony, Mahesh, SEGERS, Jesse, CHADWICK, Clint, \& SHYAMSUNDER, Aarti. (2018). Leadership development practice bundles and organizational performance: The mediating role of human capital and social capital. Journal of Business Research, 83(2018), 120-129. fevereiro.

Wang, Zhining; Sharma, Pratyush Nidhi; Cao, Jinwei. (2016). From Knowledge sharing to firm performance: a predictive model comparison. Journal of Business Research. 92(1), 192-207.

XIX Congreso Internacional del CLAD sobre la Reforma del Estado y de la Administración Pública, 2014, Ecuador, Quito. Anais... Fontes Filho, Joaquim Rubens. (2014). Da Nova Gestão Pública à Nova Governança Pública: as novas exigências de profissionalização da função pública. 